$\xi=$

\title{
The Improvement of Inter-Firm Linkages Within Dormant Mse Cluster: a Case of East Java
}

\author{
Arif Hoetoro $^{* 1}$, Deni Aditya Susanto² \\ ${ }^{1,2}$ Faculty of Economics and Business, Brawijaya University, INDONESIA. \\ *Corresponding author E-mail: arifhoetoro123@gmail.com
}

\begin{abstract}
The stagnant development of MSE clusters might be a priority concern of the government. It has been expected that such clusters need proper policies and regulations to well develop. In East Java, for instance, policies to improve inter-firm linkages within MSE cluster has been perceived as a vital effort to activate the dormant cluster. An effective inter-firm linkages will support the clustered MSEs to overcome their isolation problems so as to augment their productive capacity and enlarge output distribution. By taking the cluster of "Wisata Panci" in Pasuruan, East Java" as research object, this research revealed that inter-firm linkages are very beneficial for the advance development of the cluster. After suffering from financial crisis in 1998, the cluster succeeded to grow and develop to be active cluster.

Methodologically, this research examined factors strengthening inter-firm linkages within the cluster by employing Analytical Hierarchy Process (AHP). In doing so, local government and cluster entrepreneurs were deeply interviewed to formulate policy choices related the strategies of inter-firm linkage improvement.

The results of this research revealed that entrepreneurs within the cluster give more stressing on forward linkage improvement. Accordingly, horizontal linkage was ranked in second place. And finally, backward linkage was ranked in third place. This study concluded that both local government and entrepreneurs have same perception to more develop the cluster to be active MSEs cluster. It seems that forward linkage, especially consumptiom linkage, plays a vital role for this purpose as clustered MSEs commonly need an effective market channel to distribute their outputs widely. However, backward and horizontal linkages are also important as the linkages support further contribution to forward linkage and spur local business
\end{abstract}

Keywords: Active cluster, AHP, dormant cluster, inter-firm linkages, small industry.

\section{Introduction}

It has been generally accepted that micro and small enterprises (MSEs) tend to agglomerate in a cluster. In view of small entrepreneurs, working in cluster is more beneficial for them as the cluster can increase their competitiveness more easily (1). Clustering is then increasingly becoming the design of industrial policies to encourage entrepreneurship, learning and productivity improvements (2). Meanwhile, Altenburg and Stamer (3) stated that clustering effects will be obtained if the clustered firms succeed to create positive externalities.

Besides advantages contributed by MSE clusters, the clusters actually face many obstacles. Tambunan (4) argued that the performance of MSE clusters in Indonesia is far behind the wellknown performance of their counterparts in other countries. This might be referred to the profile of MSE clusters which are dominated by 'artisanal' or dormant clusters signifying appropriate policies to develop the clusters (5).

Therefore, efforts to activate dormant clusters have been a priority concern of local government. In East Java, for instance, the government provided such efforts in the program of "One Village One Product" (OVOP). Based on the Ministry of Industry Regulation No. 78/M-IND/PER/9/2007, the OVOP program was designated to enhance MSEs working in small industrial clusters.
The contribution of clustering as alternative strategy for MSE development has been discussed a lot in literatures. However, these existing literatures tend to mainly describe efforts to obtain collective efficiency from the clusters (6-10) On the other hand, studies paid attention on activating dormant clusters seem to lack substance in featuring clear efforts how to do so.

This research deeply investigated efforts implemented by the government of East Java in his aim to activate MSEs clusters; especially policy factors that influence the dynamics of MSE activities. The evidences taken from "Wisata Panci" cluster in Pasuruan" revealed that making inter-firm linkages effectively become the main factor that influences the advance development of the cluster.

\section{Literature Review}

\subsection{Developemnt stages of MSE Clusters in Indonesia}

The classical work of (11) described the development of MSE clusters in Indonesia. It was said that clusters in Indonesia used to occur spontaneously, but at present they were also encouraged by public institution. Ferragina and Mazzotta (2014) then stated that cluster benefits can be obtained from localization economies, availability of specialized workers, and knowledge spillovers. All these benefits, in turn, will help MSEs to enhance their ability in open innovation. Hossain (12) proved that open innovation is 
promising means for small enterprises to overcome their challenges and increase their profitability.

Based on the degree of reliance on the local market, Burger et al (13) classified the custers into four types. First, clusters that use local inputs and sell to the local market. Second, clusters that use inputs purchased from external market and process them for sale to local markets. Third, clusters in which firms use local inputs but sell to external markets. And fourth, clusters that use external inputs and sell to external markets. More specific, (14) identified such clusters into four names; 1) Artisanal, 2) Active, 3) Dynamic, and 4) Advance clusters. In Indonesia, more than 90\% clusters are identified as artisanal or dormant clusters indicating that the development of clustering in this country is still at an infant stage.

\subsection{Policy to Develop MSEs Clusters}

Clustering policy has been a challenging way of assisting small firms to move up in the value chain (15). Similarly, Zeinalnezhad et al (16) pointed out that cluster policy facilitate small firms to increase their individual competitiveness and to take advantage of synergy effects from cooperative relations. Furthermore, Foghani et al (17) insisted that in the globalization era cluster is very important to MSEs for it can strengthen their competitive advantage. For this goal, policies on clustering must be directed to create healthy networks for MSEs to participate into global market (18).

In Indonesia, the government has provided some policies of MSE development through small industrial clusters which are believed can play an effective tool for MSE enhancement (Sandee et. al, (19). In 2009 for instance, the Ministry of Domestic Affairs issued "Surat Edaran Mendagri NO. 500/ 1404/V/Bangda-2009" that regulates the stages of cluster development as presented in Figure 1 as follows:

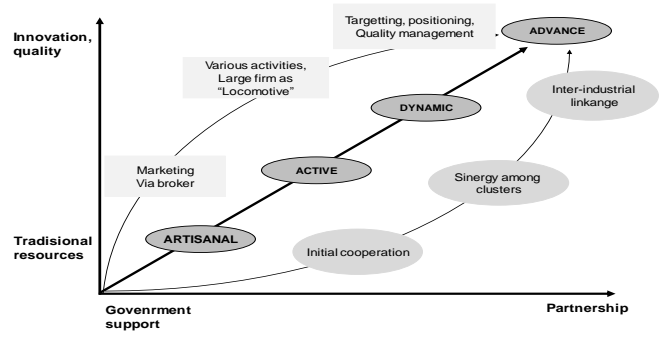

Figure 1:The Framework of Cluster Policy in Indonesia Source: Hoetoro(41)

Following other cluster policies such as UNCTAD report (20), this clustering framework basically has been aimed to stimulate small industrial cluster to grow rapidly, to improve the dynamic process of cluster, and to enhance productive capacity. To obtain these advantages, Hoetoro (10) pointed out that the dynamic process between competition and cooperation among the clustered MSEs must be promoted proportionally. The degree of cooperation and competition level evidently determines the stage of cluster development.

At initial stage, "artisanal" as the simplest form of cluster might suffer from weak cooperation. Firms in this cluster are characterized by low productivity, stagnated, use obsolete tools, and no external networks with related firms and institutions. At the next stage of development, the clustered MSEs are able to use higher skilled workers and better technology, active in marketing, and make business linkage with other firms. Joint actions among the firms help them to pick up some advantages of clustering. And finally, when clustered MSEs succeed to enhance the degree of interfirm specialization and cooperation with related institutions they have reached the type of advance cluster. The advance cluster succeeded to create inter-industrial linkages allow the firms to create competitive advantage (21).

\subsection{Inter-Firm Linkages}

Cao (22) insisted that untill the present the survival of small enterprises are not optimistic around the world. In Indonesia for instance, small enterprises are recently faced by ten major barriers to develop namely; competition barrier, financial access, price of energy, technology, inefficient production cost, economic factors, management skill, process, limitation of sales, and raw material (23).

During cluster development, creating effective inter-firm linkages plays a strategic role to over-come such defficiences. The linkages will facilitate small firms to acquire information on products and other business governance, including low price and regular supplies of inputs, availability of credits, skilled labor, and market (24). No doubt that efforts to strengthen inter-firm linkages among clustered MSEs become the heart of business chain that could be grouped into backward, forward, and horizontal linkages (25).

Backward and forward linkages are very needed to speed up the transformation process of cluster development. The linkages enable core firm to obtain production inputs, facilitate the products that are sold to final consumers and provide inputs for advanced process (26). Especially forward linkage, when MSEs can build a stable commerce in purchase or sale of goods from large firms this will guarantee their market stability. On the other hand, horizontal linkage refers to the firm that produces the similar goods at a specific level in the value chain (27).

\section{Research Method}

\subsection{Analytical Hierarchy Process}

This study intended to scrutinize and assess the transformation of "Wisata Panci", Pandaan-Pasuruan, East Java from dormant cluster to be active one. After suffering business shocks caused by financial crisis in 1997, this cluster is now going to sustain and develop steadily. For this purpose, Analytical Hierarchy Process (AHP) was used as research method.

AHP is a general theory of measurement used to derive ratio scales from both discrete and continuous paired comparisons (28). As a method Franek and (29) stated that AHP can represent human decision making process and help to achieve better judgments. These judgments were based on hierarchy, pair-wise comparisons, judgment scales, allocation of criteria weights and selection of the best alternative by calculating their utility functions.

In order to weigh the priorities of the alternatives for obtaining the desired overall ranks of the alternatives, AHP provides six steps of analysis; namely: 1) define the problem and determine the kind of knowledge sought, 2) structure the decision hierarchy, 3) construct matrices to calculate a set of pairwise comparison, 4) calculate the relative weight of the elements to each level, 5) check and balance of decision, and 6) decision documentation (30). The matrix is then used to claculate respondents' perceptions for final decision on policy choices (31).

\subsection{Research Sample}

The research sample was taken from MSEs working in the home appliance cluster called as "Wisata Panci" located in sub district Pandaan, Pasuruan, East Java. Before the monetary crisis in 1997, the cluster reached its peak. There was 70 entrepreneurs recorded actively worked in this cluster. However, the crisis then deteriorated business situation when most of entrepeneurs were forced to close their business. Nowadays, there are around 10 entrepreneurs who reactivate the home appliance cluster.

The "Wisata Panci" cluster likely succeed to obtain proximity advantage as it located insides "the Taman Dayu Resort". This resort is basically a luxurious real estate developed by Ciputra Group, the most famous national developer, that immediately 
becomes one of favorite tourism destination in East Java. To visit "Wisata Panci" cluster, visitors can pave into the entrance gate located inside "the Taman Dayu Resort". This gate provides advantages to the cluster for many tourists of the resort are attracted to come to the cluster easily for shopping souvenirs (home appliances). On the other hand, the resort provides shopping point to its visitors freely making a mutual collaboration with the cluster as depicted in Figure 2 as follows:

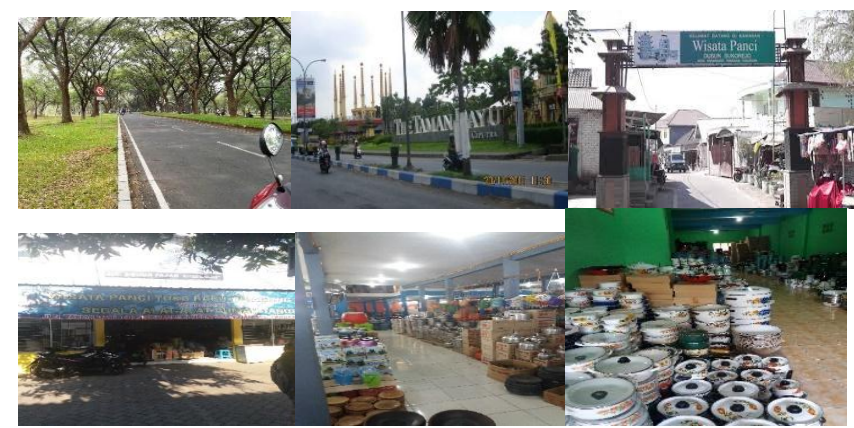

Figure 2: Location of Home Appliance Cluster and the Taman Dayu Resort

For data collection, this study employed six respondents; two respondents represented small entrepreneurs, three respondents represented officers from the Board of Regional Development Planning (Badan Perencanaan Pembangunan Daerah [Bappeda]), and one respondent represented the Office of Cooperative and SMEs (Dinas Koperasi UKM). The data collection was conducted during January-March 2017. Table 1 listed such respondents as follows:

Table 1 The Respondents

\begin{tabular}{|c|c|c|c|}
\hline No. & Name & Element & Institution \\
\hline 1 & Djoko Purwanto, S.P & \multirow{4}{*}{$\begin{array}{l}\text { Government } \\
\text { officers }\end{array}$} & BAPPEDA \\
\hline 2 & Eka Ning Siti R, S.TP & & BAPPEDA \\
\hline 3 & Alvi Hasanah, S.E & & BAPPEDA \\
\hline 4 & M. Ghozi, D.LS & & Dinas Koperasi UKM \\
\hline 5 & H. Amin Marzuki & \multirow{2}{*}{ Entrepreneurs } & $\begin{array}{l}\text { Klaster UMKM } \\
\text { Perabot }\end{array}$ \\
\hline 6 & H. Muh. Danun & & $\begin{array}{c}\text { Klaster UMKM } \\
\text { Perabot }\end{array}$ \\
\hline
\end{tabular}

\subsection{Variables and Indicators}

AHP was used to assess proper actions taken by the local government and small entreprenurs in promoting inter-firm linkages within the cluster. To do so, variables of backward, forward, and horizontal linkages were measured by some indicators as presented in Table 2 as follows:

Table 2: Items for Variables

\begin{tabular}{|c|c|c|}
\hline VARIABLES & INDICATORS & QUESTIONAIRY ITEMS \\
\hline \multirow{15}{*}{$\begin{array}{l}\text { INTER-FIRM } \\
\text { LINKAGES }\end{array}$} & \multirow{5}{*}{ Backward linkage } & Subcontract \\
\hline & & Business support to partner \\
\hline & & Giving inputs to partner \\
\hline & & Financial support \\
\hline & & Production technology \\
\hline & \multirow[t]{5}{*}{ Forward linkage } & Sharing product with partners \\
\hline & & Selling product to consumer \\
\hline & & Expand market collectively \\
\hline & & Make marketing link \\
\hline & & Receive technical support \\
\hline & \multirow{5}{*}{$\begin{array}{l}\text { Horizontal } \\
\text { linkage }\end{array}$} & Share information \\
\hline & & Share order \\
\hline & & Collective promotion \\
\hline & & Purchasing input collectively \\
\hline & & Train workers collectively \\
\hline
\end{tabular}

\section{Results and Discussion}

By utilizing AHP, the data were calculated to assess how the local government of Pasuruan and small entrepreneurs perceived efforts that needed to create and improve inter-firm linkages within the "Wisata Panci" cluster. Table 3 resumed a comparative priority between local government and entrepreneurs in improving interfirm linkages within the cluster as follows:

Table 3: Comparative Priority in Making Inter-Firm Linkages

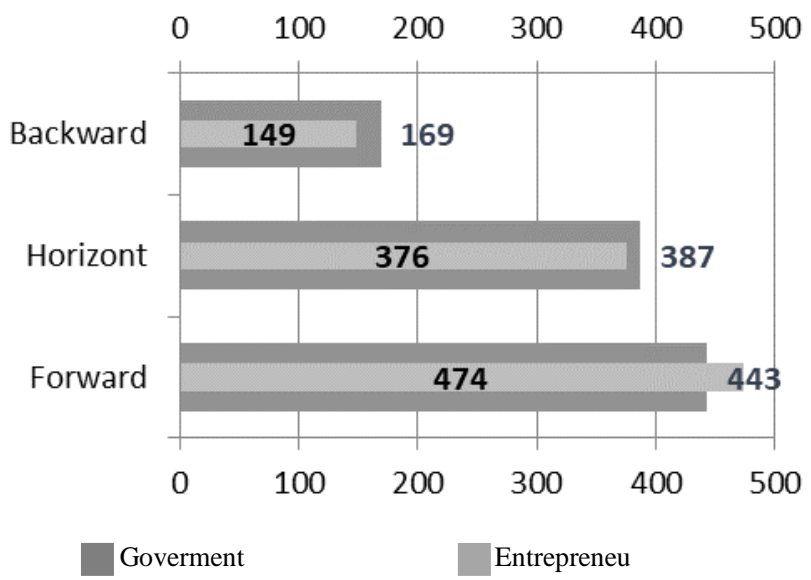

Table 3 presents the data that local government and entreprenurs have same perception on the significance of forward linkage in improving inter-firm linkages in which government scored the linkage with 443 points whereas entrepreneurs scored it with 474 points. Following (32) the same valuation between government and entrepreneur has been caused by cluster development model, internal dynamism within cluster, and business development that needs collective efficiency.

For the policy to activate "Wisata Panci" cluster, forward linkage is percieved plays a vital role. The linkage here includes the production and distribution process (9). In this context, an attention must be paid to distribution linkage when the goods reach the hands of end users (consumption linkage) charaterizing customer-oriented among the clustered MSEs to increase the final demand of cluster's product. Consequently, the interventions should help entrepreneurs to learn about their customers and introduce innovations needed to meet market demand (33).

Accordingly, horizontal linkage was placed in the second rank in which government scored it with 387 points whereas entrepreneurs scored it with 376 points. It is percieved that horizontal linkage plays another role in activating the cluster, especially in terms of information sharing and technology acquisition. To some extend, horizontal linkage is also important to develop open innovation within the cluster. James et al (34) pointed out that innovation is created through knowledge exchange and creation relationships.

For the last priority to activate "Wisata Panci" cluster, backward linkage was perceived as a channel for the clustered MSEs to maintain their supply chain with partner firms. Raposo et al (35) mentioned that firms commonly have great prospensity to develop local cooperation with their suppliers. Our research also found that making close relationship with partner firms hold essential impact for the cluster. This linkage enables such enterprises to share order, production process, raw materials, intermediate goods, business support and technology improvement.

\subsection{Forward Linkage}

Both local government and entrepreneurs percieved that the purpose to activate "Wisata Panci" cluster must be focused on forward linkage improvement. This stressing represents an urgent need among the stakeholders to sustain and increase final demand 
for their products. To do so, some activities in improving the linkages are implemented in the form of product for sale, technical support, marketing link, product sharing, and market expansion. During its development, forward linkage has provided many benefits to firms working within "Wisata Panci" cluster. The linkage is implemented by enhancing supply channel with large firms that support cluster's business. Within this linkage, MSEs obtain products of home appliance from large firms namely PT. Maspion Group Tbk and PT. Kedawung Setia Industrial Tbk. The products given to MSEs basically are sorted products in which the entrepreneurs reprocess for the finnest product. The finnest products then are sold to consumers directly and some are marketed through trading networks.

Recently, business model among the clustered MSEs gives greater prominence to forward linkages between MSEs and large firms. OECD (36) for example reported that in many countries small enterprises rely on various forms of forward linkages such as leasing, factoring, and franchise. In case of "Wisata Panci" cluster forward linkage is performed in two types namely production and consumption process. As described before that production process is established by creating a close linkage with product suppliers whereas consumption process is directly linked with consumers or is mediated by trading agency. To encourage the linkage effectively, however, some obstacles that inhibit cooperations among small enterprises and large firms must be romoved such as omit information barriers, create strong business environment, and increase benefits from the partnerships.

Maintaining forward linkage then needs some efforts to fix the linkage as a consequence of economix context. It means that at any level of cluster development, efforts should be made to maximise the benefits of relationships between enterprises. Table 4 presents activities percieved by government and entrepreneurs in order to improve forward linkage for "Wisata Panci" cluster as follows:

Table 4 Activities in Improving Forward Linkage

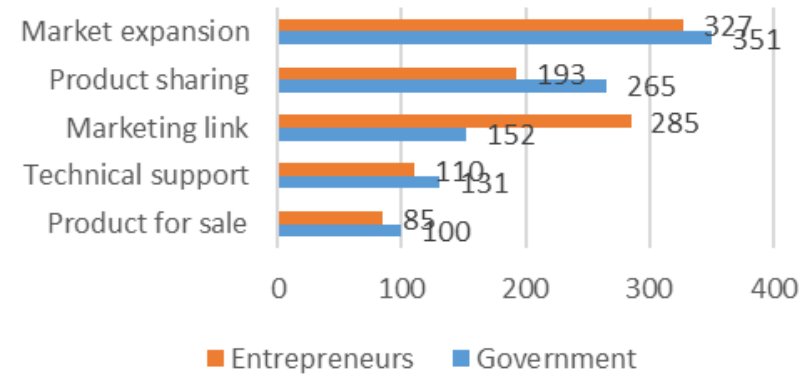

It can be reviewed from Table 4 that expanding market achieves first priority to improve forward linkage. This priority is in line with common picture of small firms' defficiencies as identified by many researches on SMEs development. Szabó (37), for example, pointed out that the main problems faced by small firms are a lack of entrepreneurial, management, and marketing skills that influences firm's ability to expand market. Rungtusanatham et al. (38) argued that the market can be expanded by creating "supplier and customer" linkage by information sharing with customers in areas of quality consistency, delivery lead time, ability to change volume quickly, and price.

To help expanding market, the entrepreneurs practically need to make an effective marketing link. They scored this priority with 285 points whereas local government scored it with 152 points. One way to promote marketing link can be realized by establishing a linkage with the Chamber of Industry or trading agency that fasilitates promotion of supply network development between MSEs and large firms (39). When supply network development is succesfully promoted, firms within the cluster can share their product with partners helping them to sale the product more easily.

\subsection{Horizontal Linkage}

Optimizing horizontal linkage within cluster is not easy for individual enterprises are often doubtful to the results of network mechanism. This is related to the assumption that entrepreneurs must bear costs of mistrust and opportunistic behaviour with their partners. In another side, firms working within cluster basically need to cooperate each other in order to overcome their business obstacles. Hoetoro (10) insisted that combining cooperation and competition proportionally is a key to get collective efficiency of cluster.

Horizontal linkage emerges when firms within cluster collaborate and cooperate with each other in the same manner of value chain. This linkage includes joint marketing of product, joint purchase of input, sharing of capacity, common use of equipment, trade fairs, and joint product development.Table 5 presents some activities percieved by local government and entrepreneurs in order to improve horizontal linkage in "Wisata Panci" cluster as follows:

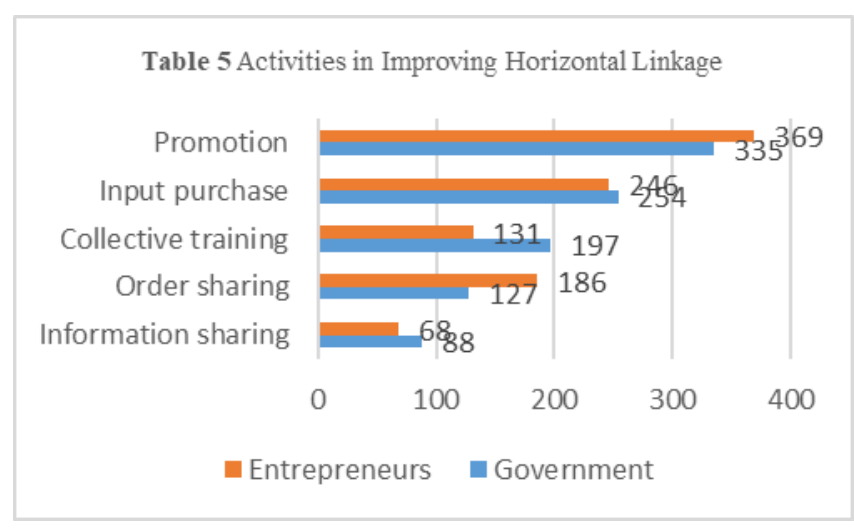

Some potential advantages picked up from horizontal linkage enable the clustered firms to improve economies scale, increase negotiation power, capacity for learning, innovation, and capacity of strategic management. Table 5 shows that collective promotion is placed in the first rank of activities performed by entrepreneurs (369 points) and local government (335 points). UNIDO (39) suggested that collective promotion and input purchase can be implemented through broker or intermediary agency. For this, public sector agency, professional association, and NGO can take over the task.

Accordingly, improving collective training is percieved will help the clustered firms to improve horizontal linkage quality. A more attention is given by local government as this activity was scored 197 points compared to 131 points given by entrepreneurs. However, order sharing seems to be more prioritized by entrepreneurs (186 points) because this activity enables the clustered firms to augment their capacity in selling product. Following (40) that efforts to strengthen horizontal linkage will benefit the clustered firms to share risks and access to market.

\subsection{Backward Linkage}

Activities in backward linkage seems to be limited among the entrepreneurs of "Wisata Panci" cluster. This might be caused by a reason that the entrepreneurs do not enjoy an economies scale from their business yet. Therefore, backward linkage was placed in the last rank shows that the linkage needs some improvements. Among activities that are needed to improve backward linkage, technical support to partners was placed in the first rank. Entrepreneurs scored this priority with 360 points whereas local government scored it with 334 points. Some entrepreneurs who subcontracted a part of product assembling need to complete this job by technical support to partner firms. Other supports in 
business and financial assistance are also provided since most of the entrepreneurs in "Wisata Panci" cluster are characterized as microentrepreneurs. The backward linkage, however, is able to spur economic activities surrounding the cluster. Table 6 presents important activities percieved by local government and entrepreneurs in order to improve backward linkage in the cluster as follows:

Table 6 Activities in Improving Backward Linkage

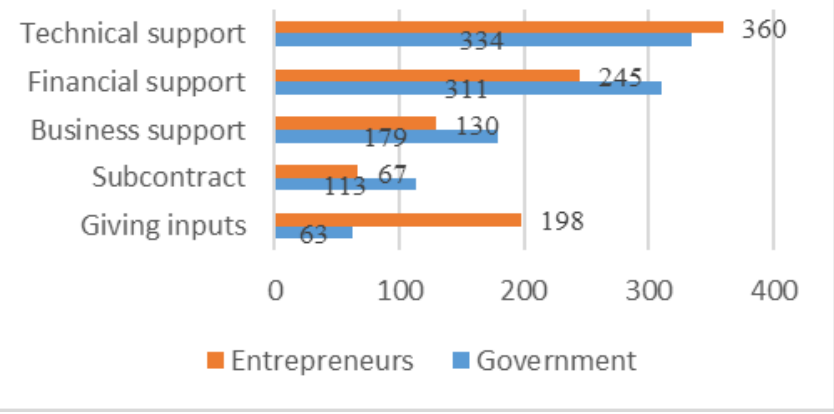

\section{Conclusion}

By taking an example from "Wisata Panci" cluster in Pandaan, Pasuruan, East Java, this study revealed that improving inter-firm linkages are important to activate the cluster from its dormant position into active one. At certain level of intensity, however, these factors are differently perceived by the local goverment of Pasuruan and cluster entrepreneurs. For the entrepreneurs promoting forward linkage is more important whereas local government gave more attention on horizontal and backward linkages.

Some activities to promote inter-firm linkage improvement then ranked enables both local government and entrepreneurs concern to support this task. Consequently, policies to activate "Wisata Panci" cluster should accomodate all activities perceived by the entrepreneurs. Improving inter-firm linkages effectively will guarantee the cluster to be more active and so as to improve its productive capacity for getting sustainable development.

\section{References}

[1] V.V. Mazur, K.A. Barmuta, S.S. Demin, E.A. Tikhomirov, M.A. Bykovskiy, Innovation Clusters: Advantages and Disadvantages. International Journal of Econo-mics and Fnancial Issues. Vol. 6. Special Issue (2016).

[2] UNIDO, Cluster development for pro-poor growth: the UNIDO approach, The United Nations Industrial Development Organization, Vienna, 2010

[3] T. Altenburg, J. Meyer-Stamer, How to Promote Clusters: Policy Experiences from Latin America, World Development, Vol. 27, No. 9 (1999) 1693-1713.

[4] T.T. Tambunan, Development of Small and Medium-Scale Industry Clusters in Indonesia, KADIN Indonesia, http://www.kadinindonesia.or.id/en/doc/opini, 2006.

[5] A.K. Çelik, E. Talaş, A.I. Akbaba, A Sectoral Hirarchical Clustering of SMEs in Turkey with Respect to General Support Programs, Review of European Studies, Vol. 5, No. 5 (2013).

[6] H. Schmitz, Collective Efficiency: Growth Path for Small Scale Industry, The Journal of Development Studies 31 (4), 1995.

[7] R. Rabellotti, Collective Effects in Italian and Mexican Footwear Industrial Clusters, Small Business Economics 10 (1998) 243-262.

[8] K. Nadvi, Collective Efficiency and Collective Failure: the Response of Sialkot Surgical Instrument Cluster to Global Quality Pressures, World Development Vol. 27, No. 9 (1999).

[9] Y. , Linkage Formation by Small Firms: the Case of Rural Cluster in Indonesia, Bulletin of Indonesian Economic Studies Vol. 36 No. 1 (2000) 137-166.
[10] A. Hoetoro, Cooperation and Competition among Clustered MSEs in East Java, Gajahmada Inter-national Journal of Business, Vol. 16 No 3 (2014) 275-293.

[11] H. Weijland, Microenterprise Clusters in Rural Indonesia: Industrial Seedbed and Policy Target, World Development Vol. 27, No. 9, (1999) 1515-1530.

[12] M. Hossain, A review of literature on open innovation in small and medium-sized enterprises, Journal of Global Entrepreneurship Research 5:6, 2015.

[13] K. Burger, D. Kameo, H. Sandee, Clustering of Small AgroProcessing Firms in Indonesia, Inter-national Food and Agribusiness Management Review, 2(3/4) (2001) 289-299.

[14] T.T. Tambunan, Development of Rural Manufacturing SME Clusters in a developing Country: the Indonesian Case, Journal of Rural Development 31 (2008) 123-146.

[15] Chaminade, C. J. Vang, Innovation Policy for Asian SMEs: Exploring Clusters Differences, WP 2006/3 (2006).

[16] M. Zeinalnezhad, M. Mukhtar, S. Sahran, The Role of Clusters and Networks in Development of Industrial SMEs. International Conference on Business and Economics Research, vol 1. LACSIT Press, Kuala Lumpur, 2011.

[17] S. Foghani, B. Mahadi, R. Omar, Promoting Clusters and Networks for Small and Medium Enterprises to Economic Development in the Globalization Era, SAGE Open. January-March 2017; 1-9.

[18] H. Tiftik, M. Zincirkiran, Effect of Clustering Activities to Copmetitive Power in Terms of SME's Innovative Management Approach, Journal of Alternative Perspec-tives in the Social Sciences, Volume 5 No. 3 (2013) 533-550.

[19] H. Sandee, P. Rietveld, H. Supratikno, P. Yuwono, Promoting Small Scale and Cottage Industries in Indonesia: an Impact Analysis for Central Java. Bulletin of Indonesian Economic Studies, Vol. 30, No. 3 (1994).

[20] C. Fortin, Improving the Competitiveness of SMEs through Enhancing Productive Capacity, Pro-ceedings of UN Conference on Trade and Development. New York (2005).

[21] Rawat, D, R.K. Mittal, V.S. Aggarwal, Networks with Cluster Stakeholders as a Business Strategy to Enhance Performance: A Conceptual Framework, Proceedings of International Conference in Volatile and Uncertain Environment for Emerging Markets. New Delhi, 2017.

[22] Y. Cao, A survival analysis of small and medium enterprises (SMEs) in central China and their determinants, African Journal of Business Management, Vol. 6 No.10 (2012) 3834-3850.

[23] M. Irjayanti, A.M. Azis, Barrier Factors and Potential Solutions for Indonesian SMEs, Procedia Economics and Finance 4 (2012) 312 .

[24] S. Lemma, Subcontracting Strategy for the Ethiopian Micro and Small Enterprises, Study Report submitted to Ethio-German Micro and Small Enterprises Development Programme, Addis Ababa Ethiopia, 2001.

[25] A.O. Miehlbradt, M. McVay, Implementing Sustainable Private Sector Develop-ment: Striving for Tangible Results for the Poor: The 2006 Reader, International Training Centre of the ILO, 2006.

[26] F. Mazzola, S. Bruni, The role of linkages in firm performance: evidence from southern Italy. Journal of Economic Behavior \& Organization, Vol. 43 (2000) 199-221.

[27] Li, Fung, Overview of the Industrial Clusters in China, Industrial cluster series, Issue 1. Li \& Fung Research Centre, 2006.

[28] R.W. Saaty, The Analytic Hierarchy Process-What it is and How it is Used, Mathl Modelling, Vol 9. No. 3-5 (1987) 161-176.

[29] J. Franek, A. Kresta, Judgment scales and consistency measure in AHP, Procedia Economics and Finance 12, 2014; 164-173.

[30] R.F.S.M. Russo, R. Camanho, Criteria in AHP: a Systematic Review in Literature, Procedia Computer Science 55 (2015): 1123 1132.

[31] E. Triantaphllou, S.H. Mann, Using the Analytic Hierarchy Process for Decision Making in Engineering Applications: Some Challenges. Inter'l Journal of Industrial Engineering and Practice, Vol. 2 No. 1 (1995) 35-44

[32] E. Ostorm, Collective Action and The Evolution of Social Norms, Journal of Economics Perspectives, Vol. 14 Number 3 (2000) 137 158.

[33] IDS Policy Briefing. Collective Efficiency: a Way Forward for Small Firms. Issue 10, UK. Institute of Development Studies, 1997.

[34] A. James, S. Gee, J.H. Love, S. Roper, J. Willis, Small firm-large firm relationships and the implications for small firm innovation: what do we know? ERC White Paper No. 9. www.enterpriseresearch. ac.uk, 2014. 
[35] M.L. Raposo, J.J.M. Ferreira, C.I. Fernandes, Local and crossborder SME cooperation: Effects on innovation and performance, Revista Europea de Direccion y Economia de la Empresa 23 (2014) 157-165.

[36] OECD, Encouraging Linkages between Small and Medium Sized Companies and Multinational Enter-prises: an Overview of Good Policy Practice, OECD Investment Committee, France, 2005.

[37] A. Szabó, Clustering for Competitiveness, In SME Clustering. Finding the Right Business Partners and Improving the Business Environment for SMEs, edited by Szabó and Dürkop, Konrad Adenauer Stiftung. Greece, 2016.

[38] M. Rungtusanatham, F. Salvador, C. Forza, T.Y Choi, Supply-chain linkages and operational perfor-mance: A resource-based-view perspective, International Journal of Operations \& Production Management, Vol. 23, No. 9 (2003) 1084-1099.

[39] UNIDO, Development of Clusters and Networks of SMEs, The United Nations Industrial Development Organization, Vienna , 2001.

[40] M. Ayyagari, Micro and Small Enterprises: Unexplored Pathways to Growth, MicroREPORT\#63 (2006).

[41] A. Hoetoro, Ekonomika Industri Kecil, UB-Press, Malang, 2017.

\section{Missing in References}

Ferragina and Mazzotta (2014) at page\#2

\section{Missing in Document}

B. Jankowska, Cluster organization as a pro-internationalization form of cooperation in the SME sector - a Polish case in the European context. Journal of Economics and Management. Vol. 22 (4), 2015.

Davis, C.H, D. Arthurs, E. Cassidy, D. Wolfe, What Indicators for Cluster Policies in the $21^{\text {th }}$ Century? Paper presented for Blue Sky II, Ottawa, US (2006).

Price, D.P, M. Stoica, R.J. Boncella, The relationship between innovation, knowledge, and perfromance in family and non-family firms: an analysis of SMEs. Journal of Innovation and Entrepre-neurship 2 (2013) 14.

I. Makedos, The Collaboration of SMEs through Clusters as Defense againts Economic Crisis, Economics Research International, Article ID 407375, 2014.

J. Hamdani, C. Wirawan, Open Innovation Implementation to Sustain Indonesian SMEs. Procedia Economics and Finance 4 (2012) 223-233.

K. Nadvi, S. Barrientos, Industrial Clusters and Poverty Reduction towards a methodology for poverty and social impact assessment of cluster development initiatives, UNIDO, Vienna, 2004.

M. Ganbold, The Impact of the Small and Medium Enterprise Support Programmes on the Livelihoods of Microentrepreneurs Using Sustainable Livelihood Framework: A Case Study of Enterprise Mongolia Project Phase 2 by United Nations Development Programme in Mongo-lia. Thesis. Massey University. New Zealand, 2016.

M. Gőbel, R. Vogel, C. Weber, Management Research on Reciprocity: A Review of the Literature, Business Research, Official Open Access Journa of VHB, Volume 6 Issue 1 (2013).

M. Porter, Clusters and New Economics of Competition, Harvard Business Review, 76 (1998) 77-90.

M.S. Freel, Sectoral patterns of small firm innovation, networking and proximity. Resrach Policy 32 (2003) 751-770.

O. Mauroner, Innovation Clusters and Public Policy - The Case of a Research-Driven Cluster in Germany, American Journal of Industrial and Business Management, 5 (2015) 736-747.

P. Andersen, Bollingtoft, Cluster-based global firms' use of local capabilities, Management Research Review, Vol. 34 No. 10 (2014) $1087-$ 1106

P-A. Havnes, K. Senneseth, A Panel Study of Firm Growth among SMEs in Networks, Small Business Economics 16 (2001) 293-302.

P. Ismalina, An integrated analysis of socioeconomic structures and actors in Indonesian industrial clusters. UMCG research database. University of Groningen, 2011.

R. Baptista, P. Swann, Do firms in cluster innovate more? Research Policy 27 (1998).

R.W. Gakure, P.N. Kimemia, G.A. Waititu, Influence of Subcontract Offering on the Performance of Manufacturing Micro and Small Enterprises in Kenya. IOSR Journal of Humanities and Social Science. Volume 19 Issue 1 (2014) 37-46.
S. Morse, N. McNamara, M. Acholo, Sustainable Livelihood Approach: A critical analysis of theory and practice, Geographical Paper No. 189, University of Reading, UK, 2009. 